\title{
Pemberlakuan Syari'at Islam Di Nanggroe Aceh Darussalam (NAD)
}

\author{
M. Abdul Kholiq
}

\begin{abstract}
The application of Islamic Syariah to Nangroe Aceh Darussalam which has already obtained special autonomy, based on its historically background which has a specific nature and it has already become the ideology and political agenda of the society. In addition, there is a justification based on the religious doctrine in theory of Islamic Law Reception Authority, and it also is supported by the historical facts. Even, the application of Islamic Syariah especially to the adherent of religion, it becomes Constitutional Right to the Moslems in Indonesia. It should become the obligation of a State to facilitate and guarantee the realization.
\end{abstract}

Abstrak

\section{Pendahuluan}

Salah satu fenomena yang terlihat sejak reformasi bergulir dalam kehidupan bangsa Indonesia ialah munculnya aspirasi masyarakat muslim di berbagai daerah yang menghendaki agar syari'at islam dapat diberlakukan di negeri ini, minimal di wilayah mereka.

Beberapa waktu yang lalu di Sumatra Barat misalnya, aspirasi tersebut antara lain terlihat dari kuatnya keinginan masyarakat setempat untuk memiliki sebuah Peraturan Daerah (Perda) bernuansakan Islam yang bisa menjadi dasar yuridis untuk memberantas sejumlah kemaksiatan di wilayahnya. ${ }^{1} \mathrm{Di}$ daerah lain, Perda serupa bahkan sudah disahkan dan menjadi bagian dari hukum positif yang mengatur kehidupan mereka. Misalnya Perda No.1/2000 di daerah Tasikmalaya ${ }^{2}$ dan Perda No. 2/2000 di daerah Cianjur. ${ }^{3}$ Sedangkan beberapa daerah lain lagi seperti Provinsi Banten, Sulawesi Selatan dan Kabupaten Garut tampaknya juga sudah lama terlihat adanya berbagai persiapan oleh kelompok-kelompok masyarakat muslim setempat untuk menuju ke arah yang sama yakni pemberlakuan bahkan pemformalisasian syari'at Islam. ${ }^{4}$ Saat proses Pemilihan Kepala Daerah (Pilkada) berlangsung pada pertengahan 2005 ini, di sejumlah daerah tertentu seperti Medan Sumatra Utara, aspirasi rakyat

${ }^{1}$ Majalah Sabili, Edisi No. 2 Tahun IX, 18 Mei 2001.

2 Majalah Forum Keadilan, Edisi No. 7, tanggal 20 Mei 2001.

${ }^{3} \mathrm{lbid}$.

${ }^{4} \mathrm{M}$. Imaduddin Rahmat, Jalan Alternatif Syari'at Islam, artikel dalam Majalah TashwirulAfkar, Lakpesdam -TAF, Jakarta, Edisi No. 12 Tahun 2002. 
mengenai hal tersebut pun masih terus bermunculan. Indikasinya antara lain tampak dari adanya tuntutan publik agar calon-calon kepala daerah yang terpilih nanti bersedia "teken kontrak politik" lebih dulu sebagai bentuk komitmen untuk memberantas kemaksiatan yang dikenal dengan istilah "pekat" (penyakit masyarakat). Karena hal itu diyakini merupakan tuntunan sekaligus tuntutan syari'at Islam kepada ummatnya agar selalu melakukan amar ma'ruf nahi munkar. ${ }^{5}$

Bicara masalah aspirasi pemberlakuan syari'at Islam di suatu daerah di Indonesia tentu tidak dapat lepas pula kaitannya dengan eksistensi Daerah Istimewa Aceh. Di daerah yang kemudian memperoleh otonomi' khusus sebagai Provinsi Nanggroe Aceh Darussalam (NAD) ini, aspirasi mengenai masalah tersebut bahkan terlihat lebih menonjol dan progresif. ${ }^{6}$ Hal demikian ini karena Aceh memang memiliki hak historis yang bersifat khusus. ${ }^{7} \mathrm{Di}$ samping hal itu juga memang sudah lama menjadi agenda perjuangan politik dan ideologi masyarakatnya. Bahkan separatisme yang dilakukan oleh Gerakan Aceh Merdeka (GAM) yang telah berlangsung puluhan tahun disinyalir juga berkait dengan salah satu tuntutan absolutnya yang menghendaki agar di daerah Aceh dapat diberlakukan syari'at Islam. Oleh karena itu, kebijakan pemerintah pusat Negara Kesatuan Republik Indonesia (NKRI) dalam mengesahkan UU No.44/1999 tentang Penyelenggaraan Keistimewaan Provinsi Daerah Istimewa Aceh dan UU No. 18/2001 tentang Otonomi Khusus Bagi Provinsi Daerah Istimewa Aceh sebagai Provinsi Nanggroe Aceh

${ }^{5}$ Dalam pemberitaan di berbagai media antara lain dipublikasikan bahwa proses Pemilihan Kepala Daerah Langsung untuk pasangan Walikota dan Wakil Walikota Medan Sumatra Utara belakangan ini sering diwamai dengan unjuk rasa damai oleh sejumlah masyarakat muslim di kota tersebut untuk menyampaikan aspirasi agar walikota terpilih benar-benar concern dan komit terhadap penegakan syari'at Islam.

${ }^{6}$ Berdasarkan UU No. 18/2001 tentang Otonomi Khusus Bagi Provinsi Daerah Istimewa Aceh Sebagai Provinsi Nanggroe Aceh Darussalam, pemerintah dan masyarakat muslim di daerah ini memiliki legitimasi untuk memberlakukan syari'at Islam berdasarkan undang-undang (tidak sekedar Perda seperti daerah lain) sebagai salah satu wujud/manifestasi keistimewaannya.

7 Dalam Harian Kompas edisi 13 Desember 2004 pada rubrik Teropong, diangkat tulisan tentang Jejak Islam di NAD. Dalam tulisan tersebut antara lain disebutkan bahwa kebesaran Kerajaan Samudra Pasai di Aceh waktu dulu sebagaimana termaktub dalam catatan musatir lbnu Batutah adalah sangat nyata. Perannya sungguh signifikan sebagai pintu gerbang penyebaran agama Islam ke hampir seluruh wilayah Nusantara bahkan sebagian Asia Tenggara. Saat itu hampir semua muballig yang menyebarkan Islam di Jawa dan daerah lain adalah berasal dari Pasai. Atas dasar ini, kiranya tidak berlebihan jika dikatakan bahwa tanpa keberadaan Kerajaan Samudra Pasai di Aceh, Islam di Jawa dan tempat lain di Nusantara mungkin tidak akan pernah ada. Dalam konteks demikian maka kebanggaan orang Aceh terhadap Islam dan kebesaran masa laluyang terrefleksi antara lain melalui tuntutan pemberlakuan syari'at Islam dewasa ini, memang patut dan harus dimengertidengan bijaksana. Pengakuan hak historis khusus ini juga terlihat dari salah satu bunyi konsideran (hurufb) UU No.18/ 2001 yang menyatakan "bahwa salah satu karakter khas yang alami di dalam sejarah perjuangan rakyat Aceh adalah adanya ketahanan dan daya juang yang tinggi yang bersumber pada pandangan hidup; karakter sosial dan kemasyarakatan dengan budaya Islam yang kuat sehingga daerah Aceh menjadi daerah modal bagi perjuangan dalam merebut dan mempertahankan kemerdekaan Negara Kesatuan Republik Indonesia". 
Darussalam disinyalir juga merupakan kebijakan politis yang dimaksudkan sebagai alat peredam konflik terutama dengan GAM tersebut. Walaupun hal ini tidak sepenuhnya benar. ${ }^{8}$

Dalam perspektif teori, munculnya keinginan kuat masyarakat muslim di berbagai daerah tersebut di atas, tidaklah semata-mata didasari karena mayoritas penduduk Indonesia adalah beragama Islam. Di samping ada justifikasi berdasarkan doktrin agama ${ }^{9}$ yang didukung oleh pandangan H.A.R Gibb dalam teorinya "Penerimaan Autoritas Hukum Islam", berkembangnya aspirasi tersebut secara umum juga memang dilatar belakangi oleh realitas sejarah." Bahkan menurut Hartono Mardjono, masalah pemberlakuan syari'at Islam terutama kepada pemeluknya sesungguhnya merupakan hak konstitusional ummat muslim Indonesia (berdasarkan Pasal 29 UUD 1945) yang mestinya menjadi kewajiban negara untuk menjamin dan

${ }^{8}$ Jawahir Thontowi, Self Detemination untuk Aceh: Sebuah Dilema Hukum, salah satu artikel dalam kumpulan tulisan pada buku berjudul Islam, Neo Imperialisme dan Terrorisme: Perspektif Hukum Intemasional dan Nasional, Ull Press, 2004, hlm. 106.

${ }^{9}$ Doktrin agama yang dimaksud adalah ketentuan Al-Qur'an Surat Al-Baqarah ayat 208 yang berbunyi: "Yaa ayyuhalladziena aamanuu udkhuluu fis silmi kaaffah .....". Esensi makna ayat ini memerintahkan agar setiap mukmin hendaknya berislam (meyakini dan menjalankan ajaran Islam) secara kaaffah (total dan menyeluruh) baik dalam berakidah, bersyari'ah/berhukum maupun berakhlaq.

${ }^{10}$ Berdasarkan doktrin agama yang bersumber pada Q.S Al-Baqarah:208 di ats, H.A.R Gibb dalam teorinya "Penerimaan Autoritas Hukum Islam" menegaskan bahwa ketundukan seorang muslim kepada hukum agamanya bukanlah didasarkan pada kesadaran/kerelaannya. Tetapi karena hal itu memang menjadi tuntutan dan perintah agama Islam kepada pemeluknya. Sehingga wajar dan sudah seharusnya jika dalam kenyataan banyak ditemukan ummat Islam menjalankan kehidupan hukumnya berdasarkan hukum Islam tersebut. Uraian lebih rincimengenaihal ini antara lain dapat dibaca tulisan Ichtijanto,S.Atentang Pengembangan Teori Berlakunya Hukum Islam Di Indonesia, salah satu kumpulan artikel dalam buku Hukum Islam di indonesia: Perkembangan dan Pembentukan, Tjun Surjaman (Ed.), Penerbit PT: Remaja Rosda Karya, Bandung, 1991, hlm. 114-117. Lihat juga Bustanul Arifin, Pelembagaan Hukum Islam di Indonesia, Gema Insani Press, Jakarta, 1996, hlm.35.

"Dalam riset yang kemudian melahirkan teoriyang dikenal dengan istilah Receptie in Complexu, L. W. Christian Van Den Berg menjelaskan bahwa pemberlakuan syari'at Islam sebagai dasar penyelesaian yuridis atas problema yang dihadapi masyarakat muslim Indonesia adalah memang sudah semestinya. Sabab kenyataan sejarah terutama di beberapa daerah berbasis Islam (sepertiAcëh, Makassar, Madura dan lain-lain) menunjukkan bahwa hukum Islam telah menjadi bagian dari institusi sosial yang digunakan dalam menyelesaikan berbagai persoalan. Oleh karenanya sejarah juga menunjukkan bahwa pada masa pemerintahan VOC maupun Hindia Belanda, berlakunya Syari'at Islam sebagai hukum positif bagi masyarakat muslim Indonesia tersebut pernah dilegitimasi dalam aturan setingkat konstitusi saat itu yakni. "Compendium Freijer" dan Pasal 75 ayat (3) "Regeerings Reglemenf'. Riset dan kesimpulan pandangan Van Den Berg di atas labih lanjut dapat dibaca dalam tulisan Sayuti Thalib, Receptio a Contrario: Hubungan Hukum Adat dengan Hukum Islam, Bina Aksara, Jakarta, 1985, hlm. 7. Lihat juga M. Idris Ramulya; Asas-Asas Hukum Islam: Sejarah Timbul dan Berkembangnya Kedudukan Hukum Islam dalam Sistem Hukum di Indonesia, Sinar Grafika, Jakarta, 1995, hlm. 54. Sedangkan mengenai masalah eksistensi Compendium Freijer dan Regeering's Reglement dapat dibaca K.N Sofyan Hasan dan Warkum Sumitro dalam bukunya Dasar-DasarMemahami Hukum Islam di Indonesia, Usaha Nasional, Surabaya, 1994, hlm. 140. 
memfasilitasi perwujudannya. ${ }^{12}$

Terlepas dari sinyalemen politik sebagaimana dipaparkan terdahulu, ada satu hal yang patut digaris bawahi berkait dengan tema pokok tulisan ini yaitu masalah pemberlakuan syari'at Islam di Nanggroe Aceh Darussalam. Bahwa respon mengenai hal tersebut seharusnya tidak boleh dipandang cukup hanya dengan telah diakomodasi dan dilegitimasinya melalui perundang-undangan yang ada. ${ }^{13}$ Karena di luar itu, masih banyak agenda lain yang mesti harus dikerjakan atau disempurnakan agar wacana pemberiakuan syari'at Islam di NAD benar-benar memiliki fundamen kuat (prospektif) dan bersifat operasional alias tidak problematik serta tidak terus menerus hanya menjadi diskursus. Berbagai agenda tersebut misalnya berkait dengan penyempurnaan dasar hukum, kualitas dan kuantitas sumber daya manusia (SDM) aparat, sarana prasarana dan lain-lain yang memang sangat penting untuk mendukung efektifitas implementasi syari'at Islam dalam praktik peradilan.

Harus dipahami bahwa efektifitas tersebut tentu membutuhkan kejelasan konsep/ batasan tentang hukum (syari'at) Islam yang hendak diberlakukan baik itu berupa hukum materiel, formil maupun eksekutorielnya. Begitupun dengan aparat pelaksananya. Jika syari'at Islam yang hendak ditegakkan adalah bidang pidana publik yang disebut jinayat misalnya, maka konsekuensinya ${ }^{\text {, }}$ tentu membutuhkan personil-personil handal dalam jajaran kepolisian, kejaksaan maupun kehakiman yang sungguh-sungguh menguasai ketentuan hukum pidana Islam (jinayat) tersebut.

Bertolak dari peta permasalahan di atas, maka maksud kehadiran tulisan ini ialah mencoba untuk memberikan sedikit kontribusi akademik dalam rangka merealisasikan berbagai agenda tersebut.

\section{Dasar Yuridis dan Prospektifitas}

Dalam Pasal 18 B ayat (1) UUD 1945 hasil Amandemen Kedua, dinyatakan bahwa: "Negara mengakui dan menghormati satuansatuan pemerintahan daerah yang bersifat khusus atau bersifat istimewa yang diatur dengan undang-undang". Selanjutnya dalam ayat (2)-nya ada penegasan pula bahwa: "Negara mengakui dan menghormati kesatuan-kesatuan masyarakat hukum adat beserta hak-hak tradisionalnya sepanjang masih hidup dan sesuai dengan perkèmbangan masyarakat dan prinsip Negara Kesatuan Republik Indonesia yang diatur dalam undang-undang".

Bagi daerah Aceh, jaminan konstitusional tentang pengakuan dan penghormatan terhadap keistimewaan yang dimilikinya tersebut, sesungguhnya merupakan respon sekaligus penegasan tentang keistimewaan daerah ini yang sebelumnya telah dinyatakan

${ }^{12}$ Hartono Mardjono, Menegakkan Syariat Islam dalam Konteks Ke-Indonesiaan, Mizan, Bandung, 1997, hlm. 28.

${ }^{13}$ Selain UU No.44/1999 dan UU No.18/2001, masalah pemberlakuan syari'at Islam di Nanggroe Aceh Darussalam juga telah diatur lebih lanjut dalam perundang-undangan lain baik berupa payung hukum nasional maupun regional (semacam Perda yang di Aceh disebut dengan istilah Qanun). Misalnya Keputusan Presiden (Keppres) No.11/2003 tentang Mahkamah Syar'iyyah, Qanun Provinsi NAD No.10/2002 tentang Peradilan Syari'at Islam dan Qanun Provinsi NAD No. 11/2002 tentang Pelaksanaan Syar'ah Islam Bidang Aq̣idah, Ibadah dan Syi'ar islam. 
dalam Ketetapan MPR No.IV/MPR/1999 dan kemudian dijabarkan dalam UU No.44/1999 tentang Penyelenggaraan Keistimewaan Provinsi Daerah Istimewa Aceh.

Substansi UU No.44/1999 sendiri, secara keseluruhan sebenarnya menegaskan 4 (empat) keistimewaan yang dimiliki Aceh. Pertama, ialah keistimewaan untuk dapat menerapkan syari'at Islam di seluruh aspek kehidupan masyarakat. Kedua, menggunakan kurikulum pendidikan berdasarkan syariat islam tanpa mengabaikan kurikulum umum. Ketiga, memasukkan unsur adat dalam struktur pemerintahan desa (keuchik). Keempat, mengakui peran ulama dalam penetapan kebijakan daerah. ${ }^{14}$

Khusus untuk mewujudkan keistimewaan pertama yakni penerapan syari'at Islam dalam kehidupan bermasyarakat, pada tanggal 9 Agustus 2001 telah disahkan UU No.18/2001 tentang Otonomi Khusus Bagi Provinsi Daerah Istimewa Aceh Sebagai Provinsi Nanggroe Aceh Darussalam (NAD).

Regulasi UU No.18/2001 ini sebagian besar lebih merupakan pengaturan terhadap masalah struktur kelembagaan daerah Aceh sebagai Provinsi NAD. Seperti susunan, kedudukan, kewenangan dan keuangan pemerintah daerah Provinsi NAD, badanbadan eksekutif, legislatif maupun yudikatif daerah dan lain sebagainya.

Sepanjang berkait dengan masalah implementasi syari'at Islam dan penegakan hukum terhadap pelanggaran syari'at tersebut, undang-undang ini hanya mengatur keberadaan beberapa lembaga spesifik. Seperti Mahkamah Syariyyah Provinsi dan Mahkamah Syariyyah tingkat kabupaten serta keberadaan lembaga kepolisian dan kejaksaan di daerah Aceh sebagai provinsi NAD. Sekali lagi hal inipun hanya bersifat pengaturan eksistensial kelembagaan.

Jadi hal-hal yang bersifat substansi hukum, misalnya apa yang dimaksud dengan syari'at Islam yang hendak diberlakukan dan ditegakkan, mencakup bidang apa saja, bagaimana mekanisme/prosedur penanganannya (alahkaam al-murofa'ah) jika terjadi pelanggaran dan lain-lain, tampaknya tidak dijangkau pengaturannya oleh undang-undang ini. Undang-undang ini juga tidak menegaskan aturan mengenai apa saja yang merupakan fungsi, tugas dan kewenangan dasar Mahkamah Syar'iyyah dan lembaga-lembaga lain terkait seperti kepolisian dan kejaksaan daerah sebagai institusi resmi penyelenggara peradilan di Aceh berdasarkan hukum Islam

\footnotetext{
${ }^{14}$ Topo Santoso, Aspirasi Syari'at Islam Di Era Otonomi, salah satu artikel dalam kumpulan tulisan pada buku berjudul Membumikan Hukum Pidana Islam: Penegakan Syari'at dalam Wacana dan Agenda, Gema Insani Press, Jakarta, 2003, hlm. 109. Periksa juga keseluruhan substansi dari UU No.44/1999. Menurut Azahari, empat keistimewaan Aceh yang ditegaskan dalam UU No.44/1999 tersebut, pada era 1959-an sebenarnya pernah dirumuskan sebagai konsep pemerintah pusat di bawah Tim yang diketuaj oleh Mr. Hardi dalam upaya menyelesaikan dan menciptakan kerukunan nasional di daerah Serambi Mekah ini. Namun dalam perjalanan waktu dan karena situasi politik represif saat itu yang terus berlangsung hingga akhir rejim Orde Baru, cita-cita dan perjuangan untuk hidup dalam suasana Syari'at Islam di Aceh cenderung terhenti. Meski bukan berarti "mati". Sebab saat angin reformasi berhembus, keinginan masyarakat Aceh tersebut kembali bangkit dan berproses hingga lahir dua undang-undang responsif yakni UU No.44/1999 dan UU No.18/2001. Selengkapnya mengenai hal ini dapat baca Azhari, Mengembalikan Kejayaan Aceh Lewat Mahkamah Syar'jyah, Artikel dalam rubrik Sketsa, Warta Perundang-undangan, Edisi No.2403, tanggal 21 Oktober 2004.
} 
tadi. Begitu pula tentang masalah hubungan kelembagaan antara Mahkamah Syar'iyyah dengan lembaga-lembaga serupa di daerah lain ataupun dengan Mahkamah Agung sebagai puncak kehakiman di Indonesia.

Namun demikian, jika dicermati ketentuan Pasal 31 undang-undang tersebut maka terlihat bahwa regulasi lebih rinci dan teknis mengenai hal-hal di atas ternyata diamanatkan akan diatur lebih lanjut dalam berbagai peraturan perundang-undangan lain yang lebih rendah tingkatannya (seperti Peraturan Pemerintah, Keppres, Qanun/Perda dan sebagainya)..$^{15}$ Tentu dengan substansi yang relevan. Jadi dapat dikatakan bahwa hakekat keberadaan UU No.18/2001 ini sesungguhnya merupakan undang-undang organik (Umbrella Act) yang menjadi payung hukum bersifat dasar bagi pemberlakuan syari'at Islam di Provinsi Nanggroe Aceh Darussalam.

Bertolak dari amanat UU No.18/2001 di atas maka pada tanggal 14 Oktober 2002 pemerintah daerah Provinsi NAD telah mengesahkan berlakunya dua Qanun atau Perda sekaligus. Pertama ialah Qanun Provinsi NAD No.10/2002 tentang Peradilan Syari'at Islam dan kedua, Qanun Provinsi NAD No.11/2002 tentang Pelaksanaan Syari'at Islam Bidang Aqidah, lbadah dan Syi'ar Islam. ${ }^{16}$ Bahkan untuk melengkapi aturan tentang eksistensi lembaga Mahkamah Syar'iyyah sebagai institusi penyelenggara peradilan dalam rangka implementasi syari'at Islam di Aceh, pada tanggal 3 Maret 2003 pemerintah juga telah mengeluarkan Keputusan Presiden (Keppres) No.11/2003.

Berdasarkan semua peraturan perundangundangan yang telah dikemukakan di atas, maka dapat disimpulkan bahwa dasar hukum mengenai masalah pemberlakuan syari'at Islam di NAD sesungguhnya sudah sangat kuat dan komprehensif. Karena semua bentuk landasan yuridis yang dibutuhkan mulai dari konstitusi, undang-undang, Keppres hingga peraturanperaturan di bawahnya yang terrendah seperti Qanun/Perda, telah dibuat dan disahkan untuk mem-back up pemberlakuan syari'at Islam tersebut. Oleh karena itu tidak ada keraguan sedikitpun untuk menegaskan bahwa pemberlakuan syari'at Islam di Nanggroe Aceh Darussalam sesungguhnya amat prospektif.

Hal demikian ini berbeda dengan daerahdaerah lain yang pada umumnya hanya memiliki dasar yuridis berupa Perda. Itupun dengan cakupan atau ruang lingkup makna syari'at Islam yang sangat terbatas. Yakni hanya berkait dengan penegakan hukum terhadap hal-hal yang merupakan larangan

${ }^{15}$ Secara lengkap buriyi Pasal 31 UU No.18/2001 yang terdiri atas dua ayat adalah sebagai berikut: Ayat (1) "Ketentuan pelaksanaan undang-undang ini yang menyangkut kewenangan pemerimntah ditetapkan dengan Peraturan Pemerintah (PP)". Ayat (2) "Ketentuan pelaksanaan undang-undang ini yang menyangkut kewenangan Pemerintah Provinsi Nanggroe Aceh Darussalam ditetapkan dengan Qanun (baca: Perda pen.)Provinsi Nanggroe Aceh Darussalam.

${ }^{16}$ Sebelum kedua Qanun/Perda di atas lahir, pada tahun 2000 Pemerintah Daerah Istimewa Aceh sebenarnya telah pula mengesahkan 4 (empat) perda sekaligus yang merupakan paket aturan dalam rangka menindak lanjuti lahirnya UU No.44/1999. Empat Perda tersebut ialah (1) Perda No.3/2000 tentang Tata Kerja Majelis Permusyawaratan Ulama (MPU); (2) Perda No.5/2000 tentang Pelaksanaan Syari'at Islam di Aceh; (3) Perda No.6/2000 tentang Penyelenggaraan Pendidikan berbasis Islam dan (4) Perda No.7/2000 tentang Penyelenggaraan Kehidupan Adat. 
syari'at yang disebut "ma'shiyyaf" atau secara sosiologis populer dengan sebutan "pekat" (penyakit masyarakat) berupa judi, pornografi, pornoaksi, narkoba, dan lain sebagainya. ${ }^{17}$

Untuk menggambarkan luasnya cakupan makna Syari'at islam yang dimaksud dan hendak diimplementasikan di Provinsi NAD dibanding daerah lain, mungkin dapat disebutkan ketentuan Pasal 1 angka 1 Qanun/ Perda No.10/2002. Di sini dijelaskan bahwa makna Syari'at Islam itu meliputi tuntunan ajaran Islam dalam semua aspek kehidupan yang pada pokoknya terdiri atas tiga substansi ajaran yaitu aq̣idah, syari'ah (baik dalam arti aturan hukum mengenai ibadah maupun mu'amalah) dan akhlaqul kariemah. Ketiga ajaran Islam tersebut, menurut bahasa hukum Qanun/Perda No.11/2002 disebut dengan istilah aqidah, ibadah dan syi'ar Islam.

Selanjutnya dalam Pasal 49 Qanun No.10/ 2002 ditegaskan pula bahwa Mahkamah Syar'iyyah sebagai lembaga resmi dalam konteks implementasi Syari'at Islam di NAD, memiliki tugas dan wewenang memeriksa, memutus dan menyelesaikan perkara-perkara yang timbul di masyarakat dalam bidang ahwal as-syakhshiyyah, mu'amalah dan jinayah. Sedangkan yang dimaksud dengan substansi tiga bidang perkara tersebut, menurut penjelasan Pasal 49 Qanun itu sendiri adalah mencakup ruang lingkup makna sebagai berikut:

a. Bidang Ahwal As-Syakhshiyyah adalah meliputi hal-hal yang diatur dalam Pasal 49 UU No.7/1989 tentang Peradilan Agama beserta penjelasan dari pasal tersebut yaitu mencakup masalah perkawinan, waris, dan wasiat kecuali wakaf, hibah dan sedekah;

b. Bidang Mu'amalah adalah meliputi hukum kebendaan dan perikatan seperti jual beli, hutang piutang, qiradl (pemodalan), musagah, muzara'ah, mukharabah (bagi hasil pertanian), wakilah (kuasa), syirkah (perkongsian), 'ariyah (pinjam meminjam), hain (penyitaan harta), syufah (haklanggeh), rahnun (gadai), ihyaa'ul mawat (pembukaan lahan), ma'din (tambang), luqathah (barang temuan), perbankan, ijarah (sewa menyewa), takaful (asuransi), perburuhan, harta rampasan, waqaf, hisbah, shadaqah dan hadiah.

c. Sedangkan bidang Jinayah (perkara pidana menurut ajaran (slam) adalah berupa kasus jarimah (tindak pidana) Hudud yang meliputi: Zina (hubungan seksual antara lelaki dan perempuan di luar ikatan pernikahan yang sah), Qadzaf (menuduh zina tanpa bukti), Saraqah (pencurian), Khirobah (perampokan), Syurbah (minuman keras dan napza/narkoba), Riddah (keluar dari Islam/penghinaan terhadap ajaran Islam) dan Bughat (pemberontakan). Masih termasuk yang dimaksud bidang jinayah ini adalah perkara dalam kasus jarimah Qishash baik berupa tindak pidana pembunuhan ataupun penganiayaan dan kasus jarimah ta'zier (tindak pidana di luar hudud dan qishash) seperti judi, khalwat, meninggalkan shalat fardlu serta puasa Ramadhan dan lain sebagainya.

Kemudian dalam Qanun/Perda No.11/ 2002 tentang Pelaksanaan Syari'at Islam Bidang Aqidah, Ibadah dan Syi'ar Islam ada

${ }^{17}$ Perhatikan misalnya beberapa isi peraturan daerah (Perda) yang sudah sah berlaku di suatu daerah. Seperti Perda No. 1/2000 untuk Daerah Tasikmalaya dan Perda No.2/2000 untuk Daerah Cianjur. 
pula suatu ketentuan yang bersifat lebih memperjelas bahkan memperluas cakupancakupan masalah yang harus ditaati oleh masyarakat muslim di Aceh yang jika dilanggar akan berkonsekuensi pada penuntutan pidana. Karena hal-hal itu telah ditetapkan sebagai jarimah (tindak pidana/kriminal) yang penanganannya juga menjadi kewenangan Mahkamah Syar'iyyah. Misalnya ketentuan pada Bab VIII Pasal 20-23 yang mengancam pidana ('uqubah) tertentu pada siapapun yang menyebarkan faham/aliran sesat dalam beraqidah Islam, tidak melaksanakan sholat fardlu (termasuk ibadah sholat jum'at), tidak memberi kesempatan pada orang yang ingin mendirikan sholat fardlu, tidak melaksanakan puasa Ramadlan atau menyediakan fasilitas/ peluang kepada muslim untuk tidak melaksanakan puasa Ramadlan, dan tidak berbusana Islami.

Kriminalisasi terhadap hal-hal di atas adalah didasari oleh semangat agar setiap muslim dapat tetap menjaga aqidah Islamnya secara benar ('aqiedah shahiehah), dapat meningkatkan pelaksanaan kewajiban ibadahnya dan mampu memelihara hidup istiqomah dengan melakukan syi'ar Islam sebagai agamanya. ${ }^{18}$

Sekali lagi, bertolak dari paparan perundang-undangan di atas maka masalah pemberlakuan syari'at Islam di Nanggroe Aceh Darussalam sesungguhnya merupakan sesuatu yang sangat nyata prospek dan peluang implementasinya serta tidak lagi sekedar sebuah wacana. Hal ini karena dasar hukum, substansi hukum, kelembagaan hukum maupun kultur hukum masyarakat
Aceh yang dikenal Islami, semuanya tëlah tersedia sebagai fundamen pokok untuk keperluan implementasi tersebut. Tentu harus disadari pula di sini bahwa ketersediaan berbagai fundamen tersebut tetap masih membutuhkan penyempurnaan karena adanya berbagai kelemahan yang terdapat $\mathrm{di}$ dalamnya. Misalnya substansi hukum yang masih belum dilengkapi dengan keberadaan hukum formil dan hukum eksekutoriel, belum terbentuknya beberapa lembaga tertentu sebagai komplemen dan penunjang sistem peradilan Islam dan lain-lain.

Persoalannya sekarang adalah bagaimana masyarakat Aceh dan pemerintah daerah setempat dapat menunjukkan kemauan sekaligus kemampuan untuk menjawab berbagai kelemahan di atas agar implementasi syari'at Islam di daerah Aceh benar-benar bisa berjalan efektif dan optimal.

Dalam konteks demikian, kiranya mutlak ada langkah identifikasi sekaligus solusi terhadap berbagai hal yang menjadi problema atau potensial dapat menghambat efektifitas tersebut. Ini berarti diperlukan pencermatan spesifik tentang berbagai faktor yang berpengaruh terhadap berlakunya hukum/ syari'at Islam dalam masyarakat Nanggroe Aceh Darussalam.

\section{Faktor Pendukung Efektifitas}

Dalam perspektif teor mengenai efektifitas berlakunya hukum di masyarakat, Soerjono Soekanto pernah menjelaskan bahwa hal itu setidaknya dipengaruhi oleh 4 (empat) faktor. Pertama ialah kaidah hukum atau peraturan

${ }^{18}$ Baca Penjelasan Umum Alenia ke-7 dan 8 Qanun Provinsi Nanggroe Aceh Darussalam No.11/2002 tentang Pelaksanaan Syari'at Islam Bidang Aqidah, Ibadah dan Syi'ar Islam. 
yang diberlakukan itu sendiri. Kedua petugas/ aparat yang menerapkan atau menegakkan hukum. Ketiga fasilitas/sarana prasarana yang diharapkan dapat mendukung pelaksanaan hukum dan keempat warga masyarakat yang terkena ruang lingkup berlakunya hukum tersebut. ${ }^{19}$ Dalam bahasa lain yang lebih sederhana, Lawrance Friedmann sebagaimana dikutip oleh Satjipto Rahardjo juga pernah menyatakan bahwa sesungguhnya minimal ada tiga komponen sistem hukum sebagai sub sistem yang berpengaruh terhadap bekerjanya hukum dalam masyarakat, yaitu: substansi hukum (perundang-undangan), struktur hukum (kelembagaan termasuk professionalitas dan integritas aparat pelaksana hukum) dan kultur/ budaya hukum sebagai nilai-nilai dan sikap masyarakat yang mengikat sistem hukum itu. ${ }^{20}$

Berdasar kerangka pikir di atas, maka masalah prospek dan efektifitas pemberlakuan Syari'at Islam di Nanggroe Aceh Darussalam sesungguhnya juga berkait dengan setidaknya 3 (tiga) faktor tersebut, yaitu:

1. Faktor Substansi Hukum (dalam hal ini adalah berupa Hukum/syari'at Islam baik aspek hukum materielnya, formilnya maupun eksekutorielnya)

2. Faktor Struktur/Kelembagaan Hukum seperti kepolisian, kejaksaan dan pengadilan yang spesifik sebagai lembaga pelaksana Syari'at Islam serta Wilayatul Hisbah sebagai lembaga pengawas pelaksanaan
Syari'at Islam. Termasuk dalam konteks Struktur/Kelembagaan Hukum ini ialah profesionalitas dan integritas moral aparat pelaksana hukum.

3. Faktor Kultur/Budaya Hukum Masayarakat Aceh berkait dengan eksistensi syariat Islam yang hendak diberlakukan dalam kehidupan mereka .

Mengenai faktor pertama yakni substansi hukum, meski daiam uraian terdahulu telah ditegaskan bahwa semua perundang-undangan dari berbagai tingkatan dewasa ini telah dilahirkan untuk memberikan landasan hukum dalam rangka mendukung upaya implementasi syari'at Islam di NAD, namun bukan berarti bahwa segi perundang-undangan tersebut tidak lagi ada permasalahan.

Sebab sebagaimana diketahui bicara mengenai suatu aturan hukum yang hendak dilaksanakan, pada umumnya berkait dengan kesiapan tiga aspek, yaitu (1) kesiapan hukum materiel yang ingin diberlakukan, (2) kesiapan hukum formil yang menupakan tatacara/prosedur untuk menegakkan hukum materiel saat tejjadi pelanggaran terhadapnya dan (3) kesiapan hukum eksekutoriel sebagai aturan tentang tatacara untuk melaksanakan hukum yang telah diputuskan oleh lembaga pengadilan. Dalam konteks demikian, maka masalah substansi hukum sebagai faktor pokok pertama bagi efektifitas pemberlakuan syari'at Isiam di NAD, harus dipahami bahwa hal itu memang masih

${ }^{19}$ Soerjono Soekanto, Penegakan Hukum, Bina Cipta, Jakarta, 1983 him. 30 . Keempat faktor di atas, oleh Baharuddin Lopa diringkas dalam tiga point tentang syarat tegaknya hukum dan keadilan di masyarakat. Yaitu (a) adanya peraturann hukum yang sesuai dengan aspirasi masyarakat; (b) adanya aparat penegak hukum yang profesional dan bermental tangguh atau memiliki integritas moral terpuji; dan (c) adanya kesadaran hukum masyarakat yang memungkinkan dilaksanakannya penegakan hukum. Selengkapnya mengenai hal ini dapat dibaca Baharuddin Lopa, Permasalahan Pembinaan dan Penegakan Hukum di Indonesia, Bulan Bintang,
Jakarta, 1987, hlm. 3-4.

${ }^{20}$ Satjipto Rahardjo, Hukum dan Masyarakat, Angkasa, Bandung, 1988, hlm. 106. 
ada sejumlah kelemahan/problema. Karena selain regulasi dari aspek hukum materielnya belum lengkap dan jelas, dari aspek hukum formil dan eksekutorielnya pun juga belum ada peraturan perundang-undangannya.

Kelemahan atau problema mengenai masalah di atas antara lain "diakui" sendiri oleh Qanun Provinsi NAD No. 10/2002 sebagaimana tercermin dari ketentuan Pasal 53, 54 dan 58 ayat (1). Dalam ketiga pasal ini intinya dinyatakan bahwa hukum materiel, hukum formil dan hukum eksekutoriel yang akan digunakan dalam penyelesaian perkara-perkara menyangkut ahwal as-syakhshiyyah, mu'amalah dan jinayah adalah bersumber atau harus bersesuaian dengan syari'at Islam yang ketentuannya akan diatur lebih lanjut dalam Qanun/Perda tersendiri. Selama Qanun yang dimaksud belum ada, maka dasar penyelesaiannya tetap menggunakan peraturan perundang-undangan nasional yang berlaku.

Sebagai catatan, dalam perkembangan mutakhir hingga pertengahan tahun 2005 ini, penegakan syari'at Islam bidang jinayah (hukum pidana) misalnya ternyata baru di-back up melalui sebuah Perda berupa Qanun Provinsi NAD No.13/2003 tentang Pelaksanaan Hukuman Cambuk yang hanya bisa diberlakukan terhadap pelaku tiga"jenis jarimah (tindak pidana) yaitu Maisir (judi), Khomr (narkoba) dan Zina (hubungan seksual di luar nikah antara lelaki dan perempuan). Hal ini berarti penegakan hukum terhadap berbagai macam tindak pidana lain di luar tiga jenis di atas (seperti saraqah, khirobah, riddah, qishash dan lain-lain) masih memerlukan lahirnya sejumlah Qanun tersendiri. Di samping itu, regulasi Qanun No.13/2003 pun ternyata kurang sempurna. Akibatnya saat Qanun tersebut diimplementasikan dalam dataran law enforcement sebagaimana terlihat pada pelaksanaan hukuman cambuk terhadap 15 penjudi di Kabupaten Bireuen, justru menimbulkan polemik panjang. ${ }^{21}$

Jadi dengan demikian syari'at Islam yang telah dilegitimasi oleh berbagai perundangundangan untuk bisa berlaku di Aceh tersebut secara praktis sesunguhnya belum aplicable. Karena Qanun atau perda sebagai wadah tunggal yuridis tentang wujud ketentuan hukum materiel, formil dan eksekutoriel yang bersumber dan bersesuaian dengan syari'at Islam tersebut, hingga sekarang ini belum dibuat secara sempurna. Tentu hal ini menjadi tantangan sekaligus kesempatan bagi

21 Pada hari Jum'at tanggal 24 Juni 2005, Provinsi Nanggroe Aceh Darussalam khususnya Kabupaten Bireuen telah mencatat sejarah baru berupa pemberlakuan Syari'at Islam di daerahnya dalam era abad millenium ini. Karena pada hari itu, 15 dari 26 pelaku tindak pidana maisir (judi) yang telah terbukti bersalah melalui putusan Mahkamah Syar'iyyah dilaksanakan hukuman cambuknya di depan publik. Di berbagai media massa, eksekusi hukuman ini telah menimbulkan polemik antara lain karena tata cara pelaksanaan (hukum eksekutorielnya) tidak diatur secara lebih jelas. Terutama dalam hubungannya dengan jenis pidana lain yang telah lebih dulu diderita oleh para terpidana. Sebelum dicambuk ternyata mereka telah dipenjara selama kurang lebih dua bulan. Teknis hukum cambuknya pun tidak di atur tegas misalnya menyangkut standar alat cambuk, kadar kekuatan pencambukan dan sebagainya. Belum lagi dikaitkan dengan dasar justifikasi dan falsafah tujuan jenis pidana cambuk ini terutama jika dilihat dari perspektif Hak Asasi Manusia (HAM). Polemikmengenai hal ini antara lain dapat dibaca tulisan Teuku Kemal Fasya, Hukum Cambukdan Keadilan, artikel Harian Kompas edisi tanggal 25 Juni 2005 dan tulisan Abdul Munir Mulkhan, Memperluas Qanun Cambuk, artikel Harian Jawa Pos edisi tanggal 27 Juni 2005. 
masyarakat dan pemerintah daerah Aceh untuk menunjukkan komitmennya dengan cara membuat berbagai perangkat hukum yang memang masih diperlukan tadi, sesegera mungkin.

Untuk merespon masalah di atas, secara sederhana mungkin dapat dikemukakan bahwa dalam aspek hukum materiel dari syari'at Islam misalnya, wujud ketentuanketentuannya adalah sebagaimana terdapat dalam nash al-Qur'an dan al-Hadits serta hasilhasil ittihad/interpretasi para ahli hukum Islam (mujtahid) mengenai ketentuan nash berkait dengan suatu persoalan hukum. Namun konsep berpikir demikian ini sesungguhnya belum menyelesaikan masalah. Sebab dalam perspektif figh, interpretasi nash oleh para mujtahid sebagaimana diketahui ternyata telah melahirkan pandangan-pandangan hukum yang sangat variatif. ${ }^{22}$

Oleh karena itu memang sudah seharusnya diperlukan kehadiran sebuah Qanun tersendiri untuk memperjelas sekaligus mempertegas tentang ketentuan nash dan hasil interpretasi nash versi ahli hukum Islam mana yang menjadi landasan hukum materiel untuk menyelesaikan berbagai kasus dalam lingkup tiga bidang perkara yang timbul di masyarakat muslim Aceh tersebut.
Selanjutnya dari aspek hukum formil dan eksekutoriel, urgensi pengaturan keberadaannya dalam sebuah Qanun tersendiri pun juga mutlak diperlukan. Sebab mustahil aspek hukum materiel dapat diterapkan (sekalipun telah disempurnakan dan disahkan beriakunya), jika tidak didukung oleh adanya ketentuan mengenai dua aspek hukum tersebut. Melalui keberadaan hukum formil dan eksekutoriel yang menggambarkan "potret" sebuah sistem peradilan, maka ketentuan-ketentuan dalam hukum materiel baru akan dapat digerakkan untuk berproses dan berlaku lewat putusanputusan pengadilan guna mewujudkan tujuantujuan hukum yang hakiki yaitu penegakan kebenaran dan keadilan.

Penyusunan dan penyelenggaraan sistem peradilan (melalui pembuatan dan pelaksanaan sistem hukum formil dan eksekutoriel), dalam perspektif Islam bahkan dipandang sebagai sebuah tugas dan kewajiban paling mulia. Sebab penyelenggaraan peradilan merupakan instrumen penting untuk bisa menerapkan dan menegakkan hukum-hukum Allah SWT. bagi setiap warga dan penguasa negara. ${ }^{23}$

Adapun mengenaifaktor keduayakni struktur kelembagaan hukum, harus dikemukakan pula di sini bahwa hal tersebut pun masih membutuhkan penyempumaan. Walau dewasa

${ }^{22}$ Secara klasik, dunia fikih Islam mengenal 4 (empat) madzhab atau pemikiran besar sebagai bentuk dan hasil interpretasi nash Qur'an dan Hadits tentang hukum dari suatu persoalan. Yaitu Madzhab Hanafi, Maliky, Syafi'ie dan Hambali. Dalam perkembangan mutakhir malah ada fenomena yang menunjukkan bahwa hampir di setiap negara Islam dewasa ini juga berkembang berbagai "madzhab baru" sebagai bentuk pemahaman Islam di dalam nash berkait dengan konteks nasional suatu negara. Di Indonesia misalnya, penelitian thesis Mahsun Fu'ad yang membatasi risetnya pada aspekberupa background'sosio-historis dan politis pada munculnya berbagai ijtihad oleh para ahli hukum Islam Indonesia, telah menggambarkan adanya tidak kurang 5 (lima) madzhab/pemikiran terkemuka. Yaitu madzhab fiqih Hasbi As-Shiddiqie, Hazairin, Munawir Syadzali, Masdar F. Ma'udie dan madzhab fiqih M.A Sahal Mahfudh serta Ali Yafie. Selengkapnya uraian mengenai hal ini dapat dibaca Mahsun Fu'ad' Hukum Islam Indonesia: Dari Nalar Partisipatoris Hingga Emansipatoris, LKiS, Yogyakarta,
2005, hlm. 61-121. 
ini telah tersedia/terbentuk institusi-institusi formal peradilan seperti kepolisian daerah, kejaksaan daerah dan pengadilan daerah yang disebut Mahkamah Syariyyah.

$\mathrm{Hal}$ tersebut di atas dikarenakan oleh adanya suatu kenyataan bahwa personil atau aparat hukum yang menduduki jabatan pada berbagai institusi itu sebagian besar masih belum disiapkan untuk menguasai secara professional tentang syari'at Islam yang menjadi tugas mereka untuk menegakkannya. Menurut Abdullah Puteh selaku Gubernur Provinsi NAD, sampai dengan akhir tahun 2004 lalu, meski sudah diadakan pelatihan dan pembekalan tingkat pertama mengenai hukum/syariat Islam bagi 120 hakim Mahkamah Syar'iyyah, 60 panitera, 20 juru sita, 60 polisi dan 60 jaksa, kiranya masih tetap diperlukan pelatihanpelatihan tingkat berikutnya. Bahkan masih dibutuhkan pula rekruitmen personil baru untuk menambah kuantitas guna memperkuat jajaran aparat peradilan Islam di daerah Aceh. ${ }^{24}$

Kekurangan struktur kelembagaan hukum sebagaimana dikemukakan di atas adalah belum termasuk kaitannya dengan masalah pembentukan lembaga pengawas pelaksanaan Syari'at Islam secara umum yang biasa disebut Wilayatul Hisbah. Dalam perspektif Qanun Provinsi Nanggroe Aceh Darussalam No.11/2002, eksistensi lembaga ini dikonsepkan sebagai partner untuk mendukung optimalisasi kinerja lembaga-lembaga utama dan resmi dalam peradilan Islam. Namun hingga sekarang lembaga tersebut belum terbentuk, sekalipun hal itu telah diamanatkan olehQQanun No.11/2002 itu sendiri. ${ }^{25}$

Bahkan jika Provinsi Nanggroe Aceh Darussalam sungguh-sungguh hendak mengikuti tradisi peradilan dalam sejarah Islam, maka di samping Wilayatul Hisbah mestinya perlu juga dibentuk suatu lembaga lain yang dikenal dengan istilah Nadhierul Madhalim atau sering pula disebut Wilayatul Madhalim, yaitu semacam Dewan Pengawasan Pengaduan orang-orang yang terdhalimi oleh praktek abuse of power pejabat/penguasa negara dan keluarganya. Ada juga yang menyebutkan bahwa sesungguhnya orientasi pokok keberadaan lembaga ini adalah menangani kasus-kasus konfrontasi antara rakyat dengan negara, baik itu berupa pejabat pemerintahan secara umum maupun pemimpin puncaknya yakni khalifah/ presiden. ${ }^{26}$

Jadi kesimpulannya, dalam hubungannya dengan faktor struktur hukum ini, persoalannya ialah selain kelengkapan kelembagaan yang harus segera dibentuk, juga berkait dengan kualitas dan kuantitas personil aparat hukum yang masih perlu terus ditingkatkan jumlahnya dan ditempa professionalitasnya guna mendukung optimalisasi pemberlakuan syari'at Islam di Aceh.

Soal kaitannya dengan masalah sarana prasarana untuk memperlancar penyelenggaraan peradilan Islam, kiranya gedung dan fasilitas lain yang selama ini telah dimiliki lembaga-lembaga peradilan umum (seperti Kepolisian Resort/

${ }^{23}$ Lihat pendapat Ahmad 'Ithyat sebagaimana dikutip oleh A.A Humam Abdurrahman dalam bukunya berjudul Peradilan Islam: Keadilan Sesuai Fitrah Manusia, WADI Press, Jakarta, 2004, hlm. 3.

${ }^{24}$ Warta Perundang-undangan edisi No. 2403, Op Cit.

${ }^{25}$ Lihat ketentuan Pasal 1 angka 11 jo. Pasal 14-15 Qanun Provinsi NAD No.11/2002.

${ }^{26}$ T.M Hasbi Ash-Shiddiqie, Peradilan dan Hukum Acara Islam, Pustaka Rizki Putra, Semarang, 1997, hlm. 92-95. Lihat juga A.A. Humam Abdurrahman, Peradilan Islam ..., Op. Cit, hlm. 35-38. 
Daerah, Kejaksaan Negeri/Tinggi dan Pengadilan Negeri/Tinggi) maupun Peradilan Agama, sehanusnya dapat terus difungsikan, dengan catatan operasionalisasinya harus diarahkan pada koridor sistem peradilan Islam.

Selanjutnya mengenai faktor ketiga yang dapat mempengaruhi efektifitas pemberlakuan serta bekerjanya hukum/syari'at Islam di Aceh yakni berupa kulturbudaya hukum masyarakat Aceh, pada prinsipnya dapat dikatakan tidak terlalu bermasalah. Sebab sejarah telah menunjukkan bahwa Islam dengan kultur kehidupan masyarakat Aceh ibaratnya adalah bagaikan dua sisi dari satu keping mata uang. Artinya dapat dibedakan tetapi tidak bisa dipisahkan.

Sebagai contoh untuk mendeskripsikan kesimpulan di atas, antara lain dapat dikemukakan pernyataan Van Vollen Hoven dalam bukunya berjudul "Orientasi Dalam Hukum Adat Indonesia". ${ }^{27}$ Dia menegaskan bahwa ada beberapa kasus di Aceh, dimana hukum potong tangan untuk para pencuri pernah diterapkan di daerah itu jauh sebelum bangsa Eropa (Belanda) memperkenalkan sistem hukum Barat kepada masyarakat Indonesia. Sehingga dahulu, seperti juga ditegaskan oleh Snouck Hourgronje yang pemah melakukan riset khusus di sana, di tengah kehidupan masyarakat Aceh terdapat banyak orang yang tanpa tangan karena mencuri. Banyak pula diantara para pencuri tersebut atau karena tindak pidana lainnya mengalami hukuman at-taghrieb (pembuangan/pengasingan) ke Pulau We. ${ }^{2 B}$ Fakta lain juga ditunjukkan oleh Hazairin yang menuliskan bahwa di beberapa wilayah Indonesia yang dikenal cukup kuat Isiamnya termasuk seperti di Aceh, pelaksanaan beberapa jenis hukuman yang dikenal dalam stelsel pidana Islam adalah kenyataan yang dapat dijumpai dalam praktik kehidupan masyarakat sehari-hari. Realitas tersebut secara bertahap baru terhapus sejak pemerintahan Hindia Belanda mulai mengukuhkan kekuasaannya di Indonesia dengan salah satu basis politik kolonialnya berupa de-Islamisasi. Hukuman cambuk dengan rotan yang diancamkan bagi pelaku zina, qodzafdan pemabuk yang pernah beriaku dalam daerah Gubernemen Hindia Belanda misalnya, baru dihapuskan semenjak berlakunya Stb. 1866/15. Kemudian hukuman mutilasi (potong tangan dan potong kaki untuk kejahatan pencurian/sarogoh dan perampokan/ khirobah) di daerah Aceh, juga baru dihapuskan tahun 1916 melalui pemberlakuan Pasal 14 Stb. $1916 / 4322^{29}$

Kristalisasi mengenai hubungan erat antara nilai ajaran Islam dengan kehidupan riel masyarakat Aceh dalam fakta sejarah di atas, setidaknya terlihat juga pada semboyan hidup masyarakat Aceh yang telah menjadi pegangan umum hingga sekarang. Semboyan hidup tersebut bahkan ditegaskan eksistensinya oleh

${ }^{27}$ Van Vollen Hoven sebagaimana dikutip oleh Jimly As-Shiddiqie dalam bukunya Pembaharuan Hukum Pidana Indonesia: Studi tentang Beniuk-Bentuk Pidana dalam Tradisi Hukum Fiqih dan Relevansinya Bagi Usaha Pembaharuan KUHP Nasional, Penerbit Angkasa, Bandung, 195, him. 208.

${ }^{28}$ Hukuman potong tangan dan hukuman pembuangan (pengasingan) adalah merupakan dua jenis sanksi pidana yang ada dalam stelsel pidana Islam. Di samping ke dua jenis sanksi pidana tersebut, hukum Islam juga mengenal jenis-jenis pidana lainnya seperti: qishash, cambuk, rajam, ta'ziir dan sebagainya.

${ }^{29}$ Hazairin, Sekelumit Persangkut-pautan Hukum Adat, salah satu artikel dalam kumpulam tulisan pada buku berjudul Tujuh Serangkai Tentang Hukum, Bina Aksara, Jakarta, 1985, hlm. 53-54. 
Penjelasan Umum Alenia ke-empat UU No.18/ 2001 yang bunyi lengkapnya sebagai berikut: "Adat bak Po Teumeureuhom, Hukom bak Syiah Kuala, Qanun bak Putro Phang, Reusam bak Laksamana". Artinya Adat (bersumber) dari Sultan, Hukum dari 'Ulama, Qanun dari Putri Pahang, Reusam dari Laksamana.

Berdasar semboyan hidup di atas terutama yang berbunyi Hukom bak Syiah Kuala (aturan hukum yang mengatur kehidupan masyarakat Aceh adalah yang bersumber dari 'ulama), mengandung arti pula bahwa sesungguhnya kehidupan hukum masyarakat Aceh diatur oleh hukum/syari'at Islam. Sebab aturan hukum yang ditetapkan 'ulama dan menjadi referensi masyarakat tidak lain adalah hukum/syari'at Islam yang bersumber pokok pada al-Qur'an dan alHadits.

Bertolak dari paparan di atas, kiranya dapat ditegaskan sekali lagi bahwa faktor kultur/budaya hukum masyarakat Aceh pada dasarnya tidak menjadi masalah/hambatan dalam konteks implementasi syari'at Islam di daerah tersebut. Bahkan kultur islami yang sudah mengakar dalam kehidupan masyarakat sana selama ini, justru akan menjadi nilai plus tersendiri yang dapat mendukung efektifitas berlakunya syari'at Islam tersebut. Karena aturan hukum yang hendak diberlakukan telah bersenyawa dengan nilai dan pandangan hidup masyarakatnya.

Tentu saja kesimpulan di atas perlu disertai dengan suatu catatan/syarat bahwa kultur Islami masyarakat Aceh tersebut hingga sekarang harus dapat dipertahankan bahkan mampu ditumbuhkan. Bukan sekedar cerita sejarah masa silam yang realitasnya sudah hilang akibat tergerus perkembangan zaman.
Kesimpulan

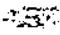

Berdasarkan uraian di atas dapat disimpulkan bahwa, aspirasi masyarakat Provinsi Nanggroe Aceh Darussalam yang menghendaki agar di daerahnya diberlakuan syari'at Islam untuk mengatur kehidupan mereka adalah sangat legitimate (absah). Karena hal itu memang dibenarkan (justified) atas dasar hak sejarah sekaligus hak konstitusional.

Untuk memberikan dasar justifikasi dan legitimasi hukum bagi pemberlakuan syari'at Islam di Aceh tersebut, dewasa ini telah dibuat dan disahkan berbagai peraturan perundangundangan yang sangat kuat dan komprehensif. Karena mencakup berbagai jenis dan tingkatan perundang-undangan yaitu mulai dari konstitusi (c.q Pasal 29 jo. Pasal $18 \mathrm{~B}$ ayat (1) dan (2) UUD 1945 Amandemen Kedua), undang-undang (c.q UU No.44/1999 jo. UU No.18/2001), Keppres (c.q Keppres No.11/ 2003) hingga sejumlah Qanun/Perda yang telah disahkan.

Namun demikian agar pemberlakuan syari'at Islam di Aceh dapat berjalan efektif, kiranya masih diperlukan berbagai kebijakan sebagai langkah penyempurnaan. Yaitu antara lain dengan membuat hal-hal sebagai berikut: (a) Qanun khusus tentang substansi syari'at Islam yang hendak diberlakukan yang mencakup tiga aspek hukum, yakni materiel, formil dan eksekutoriel; (b) Qanun /Keputusan Gubernur tentang keberadaan, fungsi, tugas dan wewenang beberapa lembaga hukum khusus seperti Wilayatul Hisbah dan Wilayatul Madhalim untuk mendukung dan mengontrol kinerja institusi-institusi resmi peraditan Isiam; dan (c) peningkatan kuantitas terutama kualitas aparat pelaksana hukum (polisi, jaksa, hakim, panitera, juru sita serta qadli willayatul 
hisbah dan wilayatul madhalim) dalam penguasaan hukum/syari'at Islam agar dapat benar-benar professional dalam menjalankan tugas dan kewajibannya atas dasar integritas moral yang tinggi.

\section{Daftar Pustaka}

A.A Humam Abdurrahman, Peradilan Islam: Keadilan Sesuai Fitrah Manusia, WADI Press, Jakarta, 2004.

A. Munir Mulkhan, Memperluas Qanun Cambuk, Artikel dalam harian Jawa Pos edisi tanggal 27 Juni 2005.

Baharuddin Lopa, Permasalahan Pembinaan dan Penegakan Hukum di Indonesia, Bulan Bintang, Jakarta, 1987.

Bustanul Arifin, Pelembagaan Hukum Islam di Indonesia, Gema Insani Press, Jakarta, 1996.

Hartono Mardjono, Menegakkan Syari'at Islam dalam Konteks Ke-Indonesia-an, Mizan, Bandung, 1997.

Hazairin, Tujuh Serangkai tentang Hukum, Bina Aksara, Jakarta, 1985.

Jawahir Thontowi, Islam, Neo Imperialisme dan Terrorisme: Perspektif Hukum Internasional dan Nasional, Uill Press, Yogyakarta, 2004.

Jimly Ash-Shiddiqie, Pembaharuan Hukum Pidana Indonesia: Studi tentang Bentuk-Bentuk Pidana dalam Tradisi Fiqih dan Relevansinya Bagi Usaha Pembaharuan KUHP Nasioal, Angkasa, Bandung, 1995.

K.NSofyan Hasan dan Warkum Sumitro, DasarDasar Memahami Hukum Islam di Indonesia, Usaha Nasional; Surabaya, 1994.

M. Idris Ramulya, Asas-Asas Hukum Islam:
Sejarah, Timbul dan Berkembangnya Kedudukan Hukum Islam dalam Sistem Hukum di Indonesia, Sinar Grafika, Jakarta, 1995.

M. Imaduddin Rahmat, Jalan Altematif Syari'at Islam, Artikel dalam Majalah Tashwirul Afkar, Lakspedam - TAF, Jakarta, Edisi No. 12 Tahun 2000.

Mahsun Fu'ad, Hukum Islam Indonesia: Dari Nalar Partisipatoris Hingga Eman-. sipatoris, LKiS, Yogyakarta, 2005.

Satjipto Rahardjo, Hukum dan Masyarakat, Angkasa, Bandung, 1988.

Sayuti Thalib, Receptio a Contrario: Hubungan Hukum Adat dengan Hukum Islam, Bina Aksara, Jakarta, 1995.

Soerjono Soekanto, Penegakan Hukum, Bina Cipta, Jakarta, 1983.

Teuku Kemal Fasya, Hukum Cambuk dan Keadilan, Artikel dalam harian Kompas edisi tanggal 25 Juni 2005.

T.M Hasbi Ash-Shiddiqie, Peradilan dan Hukum Acara Islam, Pustaka rizki Putra, Semarang, 1997.

Tjun Surjaman (Ed.), Hukum) Islam di Indonesia: Perkembangan dan Pembentukan, Remaja Rosda Karya, Bandung, 1991.

Topo Santoso, Membumikan Hukum Pidana Islam: Penegakan Syari'at dalam Wacana dan Agenda, Gema Insani Press, Jakarta, 2003.

UUD 1945 Amandemen Kedua

Tap MPR No. IV/MPR/1999

UU No.44/1999 tentang Penyelenggaraan

Keistimewaan Provinsi Daerah Istimewa Aceh

UU No.18/2001 tentang Otonomi Khusus Bagi Provinsi Daerah Istimewa Aceh Sebagai Provinsi Nanggroe Aceh 
Darussalam

Perda Provinsi D.I Aceh No. 3/2000 tentang Organisasi dan Tata Kerja Majelis Permusyawaratan Ulama

Perda Provinsi D.I Aceh No.5/2000 tentang Pelaksanaan Syari'at Islam di Aceh

Perda Provinsi D.I Aceh No. 6/2000 tentang Penyelenggaraan Pendidikan

Perda Provinsi D.I Aceh No.7/2000 tentang Penyelenggaraan Kehidupan Adat

Qanun Provinsi NAD No. 10/2002 tentang Peradilan Syari'at Islam
Qanun Provinsi NAD No.11/2002 tentang Pelaksanaan Syari'at Islam Biờng Aqidah, Ibadah dan Syilar islam

Qanun Provinsi NAD No.13/2003 tentang Pelaksanaan Hukuman Cambuk dalam Jarimah Maisir, Zina dan Khomr. Majalah Sabili, Edisi No.2 Tahun IX, tanggal 18 Mei 2001

Majalah Forum Keadilan, Edisi No. 7, tanggal 20 Mei 2001

Harian Kompas edisi tanggal 13 Desember 2004. 